\title{
Effects of a protein- and tryptophan-deficient diet upon complex maze performance
}

\author{
ANGELA H. BECKER and STEPHEN F. DAVIS \\ Emporia State University, Emporia, Kansas \\ CATHY A. GROVER \\ Texas A\&M University, College Station, Texas \\ and \\ CYNTHIA A. ERICKSON \\ Colorado State University, Fort Collins, Colorado
}

\begin{abstract}
Previous reports have suggested that protein and tryptophan deprivation might be associated with decreased mental functioning. To provide additional relevant data, two groups of rats-one protein- and tryptophan-deprived and one reared normally-were tested for learning ability in a modified Hampton Court maze. Analysis indicated that protein and tryptophan deprivation did not result in inferior maze performance.
\end{abstract}

The experimental evaluation of the effects of low-protein diets upon retarded mental capacities has been of interest for nearly 25 years. Several earlier studies (e.g., Cravioto \& Robles, 1965; Kaplan, 1972; Winick, 1976) have reported data supporting the contention that if such diets are experienced during development, then reduced mental functioning may result.

These data were based upon correlations gathered from field studies of human subjects. When such effects were subjected to more rigorously controlled experiments using animals as subjects, differences in learning were not always observed. For example, Zimmerman, Geist, and Strobel (1975) reported no differences on delayed-response and simple reversal-learning tasks by monkeys. Proteindeprived animals exhibited poorer performance than did controls on conditional discrimination, embedded-figures, and cross-string tasks. However, such inferior performance may reflect "attentional and emotional" differences rather than true cognitive deficits. Remley, Armstrong, Gilman, and Mercer (1980) reported that rats raised from weaning to maturity on a protein- and tryptophan-deficient diet of corn grits did not differ from normal littermates on a two-way active avoidance task, and were actually superior to control animals on a black-white visual discrimination task. It has also been reported that tryptophan deficiencies produce low pain tolerance (Fernstrom \& Lytle, 1976). On the two-way active-avoidance task, potential differences in learning ability may have been masked by the animals' heightened attention to painful

Portions of this paper were presented at the 1989 meeting of the Southwestern Comparative Psychology Association. Requests for reprints may be directed to Stephen F. Davis, Department of Psychology, Emporia State University, Emporia, KS 66801. stimuli. Concerning the superior discrimination performance displayed by the experimental animals, Remley et al. appealed to motivational differences as an explanation. It was suggested that the control animals were not sufficiently water-deprived. In support of this contention, it was reported that a subsequent group of normally fed animals placed on a more stringent, 23.5-h deprivation schedule exhibited a learning curve similar to the gritsfed animals.

In contrast to the reports of no difference in learning by protein-deprived and nondeprived animals, Cowley and Griesel $(1959,1963)$ observed learning deficits in deprived animals tested in the Hebb-Williams maze. Caldwell and Churchill (1967) maintained pregnant dams on a protein-deficient diet between the 11th day of gestation and delivery. Between 30 and 35 days of age, the pups were given three test trials per day for 3 consecutive days in a Lashley III water maze. Protein-deprived animals were significantly slower and made more blindalley errors than did controls. This effect, however, was limited to the first day of testing. In contrast to Remley et al. (1980), who failed to observe differences in twoway avoidance performance, Caldwell and Churchill (1967) reported that their controls performed significantly better than deprived animals on a pole-jump-avoidance task. Similarly, Turkewitz (1975) reported that normal animals were superior to protein-deprived animals on a blackwhite discrimination in a Lashley Jumping Stand apparatus.

The question of diminished cognitive capacities awaits further experimental verification. In the present study, differences in learning by rats on a tryptophan- and protein-deficient diet were observed through the use of a modified version of the traditional Hampton Court maze. This is a learning task that does not involve administra- 
tion of painful stimuli and is more complex than a simple black-white discrimination.

\section{METHOD}

\section{Subjects}

Three sperm-positive female rats were purchased from the Holtzman Company. ${ }^{1}$ These dams were maintained in individual, 10-gal aquariums having a floor of SAN-I-CEL bedding material. Purina Lab Chow and water were freely available during gestation and until the pups were weaned at 21 days of age. At weaning, all animals were individually caged in suspended, wire-mesh cages in the animal vivarium and assigned to one of two diets: normal (Purina Lab Chow) or tryptophanand protein-deficient (grits). The grits diet consisted of Quaker Instant Grits mixed with warm water to a thick, soupy consistency. Corn grits contains $0.053 \mathrm{~g}$ of tryptophan per $100 \mathrm{~g}$ and is composed of $8.70 \%$ protein (Orr \& Watt, 1957). With the exception of the deprivation periods described below, all foods and water were presented on a free-feeding basis. A total of 25 animals ( 8 grits, 17 normal) were delivered by the 3 dams and served as subjects in the present experiment.

\section{Apparatus}

The basic floor plan for the Hampton Court maze was adapted from Woodworth and Schlosberg (1961), and is diagrammed in Figure 1.

The maze was constructed of $0.32-\mathrm{cm}$ sheet metal and was approximately $1.82 \mathrm{~m}$ wide, $2.44 \mathrm{~m}$ long, and $11.43 \mathrm{~cm}$ high. The alleys were approximately $10.16 \mathrm{~cm}$ wide. A hinged top of heavy-gauge metal mesh covered the maze. Two smaller, hinged doors allowed access to the startbox located in one corner of the maze (Location A in Figure 1) and the goalbox located in the center of the maze (Location B in Figure 1). The animals could be confined to the startbox and goalbox via removable guillotine-type metal doors.

\section{Procedure}

Training consisted of three maze trials administered when the subjects were between 70 and 91 days of age. A 7-day period separated each trial.

Twelve hours prior to the first training trial, the subjects were placed on both food and water deprivation. The procedure of depriving the animals for $12 \mathrm{~h}$ prior to each training trial remained in effect for the duration of the experiment. On Trials 1 and 2, each subject received preexposure to a saccharin reinforcer in the goalbox of the maze approximately $4 \mathrm{~h}$ prior to the administration of the maze trial.

To administer a trial, the designated subject was placed in the startbox. Following a 3-sec confinement, the start door was raised and the subject was allowed to traverse the maze. The subject's route, errors, and latency to complete the maze were recorded on each trial. The sub-

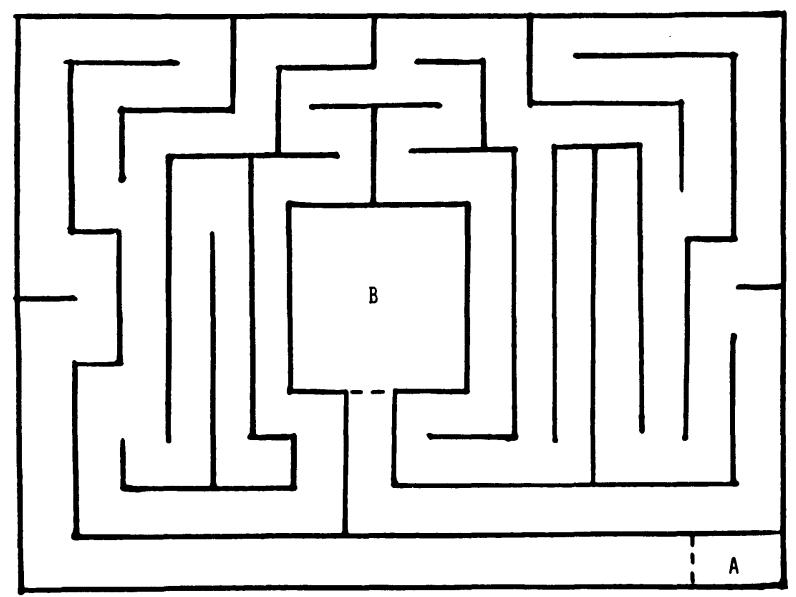

Figure 1. Floor plan of the Hampton Court maze showing the location of the startbox (A) and the goalbox (B).

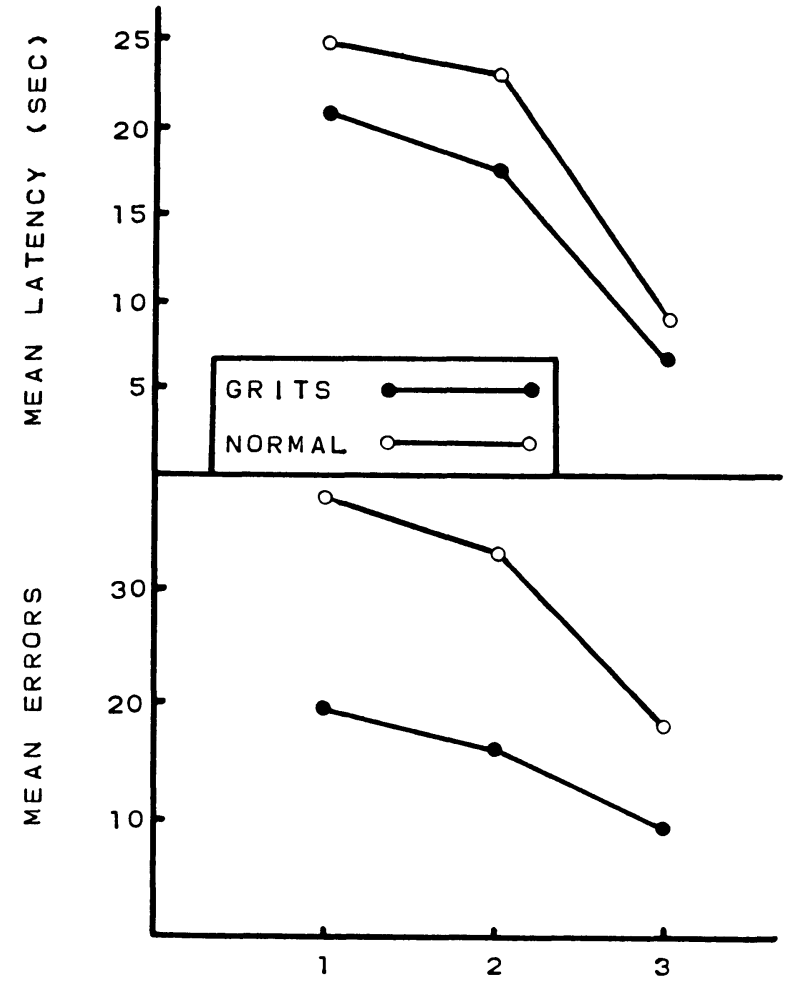

TR I ALS

Figure 2. Mean latency (in sec) to complete the Hampton Court maze (top panel) and mean errors (bottom panel) for the tryptophanand protein-deficient animals (Group Grits) and the normally reared animals (Group Normal).

ject was removed from the goalbox and returned to the home cage when it had consumed the saccharin solution for $3 \mathrm{sec}$. Subjects not completing the maze on Trials 1 and 2 were removed after $2 \mathrm{~h}$. The completion criterion was reduced to $30 \mathrm{~min}$ on Trial 3 . The maze was dampsponged and vacuumed between each trial in order to remove extraneous odor cues.

\section{RESULTS}

Figure 2 depicts the mean latencies to complete the maze (top panel) and the mean errors (bottom panel) for Trials 1-3.

A split-plot analysis of variance (ANOVA) with diet as the between-subjects factor and trials as the withinsubjects factor performed on the latency data yielded significance only for trials $[F(2,46)=6.85, p<.01]$. Subsequent Newman-Keuls tests indicated that although the latencies shown on Trials 1 and 2 did not differ from each other reliably, they were significantly longer $(p<.01)$ than those shown on Trial 3.

A similar split-plot ANOVA performed on errors yielded significance for groups $[F(1,23)=5.93, p<.02]$ and trials $[F(2,46)=5.18, p<.01]$. Clearly, the normal animals made more errors than did the grits animals. Newman-Keuls tests probed the significant trials effect and indicated that significantly $(p<.01)$ more errors were made on Trials 1 and 2 than on Trial 3. It is clear 
that learning, as measured by a decrease in latency to complete the maze and in errors, was displayed by both groups of animals.

\section{DISCUSSION}

In addition to showing that the animals were capable of mastering the Hampton Court maze, the present results address differential effects of early exposure to the protein- and tryptophan-deficient diet. At the least, the findings appear to support previous research, such as the Remley et al. (1980) study, by indicating that such early exposure does not affect learning negatively. For example, analysis of the latency scores showed no significant groups effect. Likewise, analysis of the errors did not indicate that more errors were made by the grits animals.

On the other hand, a case might be made for the deprived (grits) animals actually being superior relative to the normal animals. Although the differences were not statistically significant, it is worth noting that, as shown in Figure 2, the latencies of the grits animals were shorter than those of the normal animals. More convincingly, the grits animals made significantly fewer errors in traversing the maze (see Figure 2).

Having suggested that the grits animals may have learned the maze better than did the normal animals, one may ask why this occurred. Was it due to differential learning or to some other factor? Visual inspection of the data sheets indicated that rather than entering every possible cul de sac, the normal animals consistently made numerous repetitive errors (e.g., retracing the same incorrect path over and over and/or repeatedly approaching the goalbox but not entering it). ${ }^{2}$ This tendency was not observed in the grits animals. These results contrast with those reported by Cowley and Griesel (1959), who tested deprived and normal animals in a Hebb-Williams maze. Their deprived animals took longer to complete the maze and chose less efficient routes. Since those investigators repeatedly changed the maze pattern, a direct comparison of these data sets is not possible. However, support for motivational, as opposed to cognitive, processes seems possible in this situation. Certainly, the present results suggested that the deprived (grits) animals were capable of learning the complex Hampton Court maze as readily as their normal counterparts.

\section{REFERENCES}

Caldwell, D. F., \& Churchill, J. A. (1967). Learning ability in the progeny of rats administered a protein-deficient diet during the second half of gestation. Neurology, 17, 95-99.
CoWley, J. J., \& Griesel, R. D. (1959). Some effects of a low-protein diet on a first filial generation of white rats. Journal of Genetic Psychology, 95, 187-201.

Cowley, J. J., \& Griesel, R. D. (1963). The development of secondgeneration low-protein rats. Journal of Genetic Psychology, 103, 233-242.

Cravioto, J., \& Robles, B. (1965). Evolution of adaptive and motor behavior during rehabilitation from kwashiorkor. American Journal of Orthopsychiatry, 35, 449-464.

FernStrom, J. D., \& LyTle, J. D. (1976). Corn malnutrition, brain serotonin, and behavior. Nutrition Reviews, 34, 257-262.

Kaplan, B. J. (1972). Malnutrition and mental deficiency. Psychological Bulletin, 78, 321-334.

OrR, M. L., \& W ATT, B. K. (1957). Amino acid content of foods (Home Economics Research Report No. 4). Washington, DC: U.S. Government Printing Office.

Remley, N. R., Armstrong, D. R., Gilman, D. P., \& Mercer, L. F., JR. (1980). Effects of early protein malnutrition on learning in the rat. Bulletin of the Psychonomic Society, 16, 377-379.

TURKEWITZ, G. (1975). Learning in chronically protein-deprived rats. In G. Serban (Ed.), Nutrition and mental functions (pp. 113-120). New York: Plenum.

WINICK, M. (1976). Malnutrition and brain development. New York: Oxford University Press.

WOODWORTH, R. S., \& SCHLOSBERG, H. (1961). Experimental psychology (rev. ed.). New York: Holt, Rinehart, \& Winston.

Zimmerman, R. B., Geist, C. R., \& Strobel, D. A. (1975). Behavioral deficiencies in protein-deprived monkeys. In G. Serban (Ed.), Nutrition and mental functions (pp. 33-64). New York: Plenum.

\section{NOTES}

1. Since these animals were part of a larger project in which some subjects received a tryptophan- and protein-deficient diet from birth, random assignment of dams to potential treatments was done at this time.

2. Since there was no overlap in the distributions of such repetitive errors between the grits and normal animals, these data were not subjected to statistical analysis. 